\title{
Prevalence and analysis of Renibacterium salmoninarum infection among juvenile Chinook salmon Oncorhynchus tshawytscha in North Puget Sound
}

\author{
Linda D. Rhodes ${ }^{1, *}$, Colleen Durkin ${ }^{1,2}$, Shelly L. Nance ${ }^{1}$, Casimir A. Rice ${ }^{1}$ \\ ${ }^{1}$ Northwest Fisheries Science Center, National Marine Fisheries Service, 2525 Montlake Blvd. East, Seattle, \\ Washington 98112, USA \\ ${ }^{2}$ Present address: School of Oceanography, University of Washington, Seattle, Washington 98195, USA
}

\begin{abstract}
Renibacterium salmoninarum causes bacterial kidney disease (BKD), a chronic and sometimes fatal disease of salmon and trout that could lower fitness in populations with high prevalences of infection. Prevalence of $R$. salmoninarum infection among juvenile Chinook salmon Oncorhynchus tshawytscha inhabiting neritic marine habitats in North Puget Sound, Washington, USA, was assessed in 2002 and 2003. Fish were collected by monthly surface trawl at 32 sites within 4 bays, and kidney infections were detected by a quantitative fluorescent antibody technique (qFAT). The sensitivity of the qFAT was within an order of magnitude of the quantitative real-time PCR (qPCR) sensitivity. Prevalence of infection was classified by fish origin (marked/hatchery vs. unmarked/likely natural spawn), month of capture, capture location and stock origin. The highest percentages of infected fish (63.5 to $63.8 \%$ ) and the greatest infection severity were observed for fish collected in Bellingham Bay. The lowest percentages were found in Skagit Bay (11.4 to 13.5\%); however, there was no difference in prevalence between marked and unmarked fish among the capture locations. The optimal logistic regression model of infection probabilities identified the capture location of Bellingham Bay as the strongest effect, and analysis of coded wire tagged (CWT) fish revealed that prevalence of infection was associated with the capture location and not with the originating stock. These results suggest that infections can occur during the early marine life stages of Chinook salmon that may be due to common reservoirs of infection or horizontal transmission among fish stocks.
\end{abstract}

KEY WORDS: Renibacterium salmoninarum · Hatchery fish interactions · Logistic regression modeling · Quantitative fluorescent antibody technique $\cdot \mathrm{qPCR}$

\section{INTRODUCTION}

Declining abundance and loss of distinct populations of wild Pacific salmon continues to be a major concern in the US fisheries. A recent reassessment of the status of threatened and endangered stocks resulted in an increase in the total number of listed stocks (CFR 2005). Among captive broodstock programs developed to rebuild natural populations of salmon, bacterial kidney disease (BKD) is a persistent and debilitating problem. This disease can cause acute morbidity and mor- tality, or it can remain a subclinical and cryptic infection (Evenden et al. 1993). Furthermore, infection with the etiological agent of BKD, Renibacterium salmoninarum, can occur horizontally among cohabiting fish or vertically through intraovum transfer (Brown et al. 1990). These characteristics suggest that infection with $R$. salmoninarum could be prevalent among free-ranging salmon. While there are multiple reports of $R$. salmoninarum in salmonids during the freshwater stage (Mitchum et al. 1979, Sanders et al. 1992, Pascho et al. 1993, Maule et al. 1996, Elliott et al. 1997, Jons- 
dottir et al. 1998), there are few surveys of R. salmoninarum infection in Chinook salmon from marine coastal areas of the northwestern US (Banner et al. 1986, Arkoosh et al. 2004).

One area of concern for stock management is the potential for pathogen transfer between cultured and wild fish. Recent reports of associations between sea lice infestations in net-pen salmon and proximal wild salmon have argued for parasite transfer from farmed to wild fish (Krkosek et al. 2005). Nevertheless these results and conclusions have been disputed (Brooks 2005). The most definitive demonstration of directional fish pathogen transfer employed nucleic acid fingerprinting and showed transfer of infectious hematopoietic necrosis virus from wild to hatchery fish (Anderson et al. 2000). In that study, evidence for pathogen transmission occurred even when wild and cultured fish were segregated by physical barriers. This suggests that evidence of pathogen transmission might be detected among free-ranging populations of salmon that school and migrate together.

Northern Puget Sound in northwestern Washington State, USA, contains several river mouth estuaries and associated embayments, all of which receive freshwater and outmigrating salmon from one or more principal watersheds. These embayments vary in physical characteristics such as salinity and temperature depending on freshwater input volumes, and they also vary in accessibility to juvenile Chinook salmon from other watersheds. Based on hatchery management plans and smolt capture data, approx. $42 \%$ of the 17 million plus Chinook salmon smolts that migrated into North Puget Sound from these watersheds in 2003 were released from Federal, state and tribal hatcheries. Newly emigrating fish occupy the nearshore surface water (neritic) habitats in the months directly after outmigration, thus allowing hatchery and natural spawn fish to commingle. Hatchery fish are most frequently marked by adipose fin clipping and/or CWT implantation, and CWT markings can be deciphered to determine stock identification. The availability of hatchery markings and CWT information presents an opportunity to examine infection by Renibacterium salmoninarum with knowledge of fish origin. This study evaluated the likelihood of infection in hatchery and natural spawn fish by comparing patterns of prevalence of infection based upon hatchery marks and stock identification, while factoring for individual, geographic and environmental parameters.

\section{MATERIALS AND METHODS}

Fish capture, tissue collection and quantitative fluorescent antibody technique (qFAT). The fishing effort was designed to collect juvenile (subyearling or year- ling) Chinook salmon present in neritic sites in northern Puget Sound. The number of sites was determined by allocating the maximum geographic coverage in the embayments given the constraints of available sampling time; and site selection was based on historical catch information and predicted nearshore habitat utilization by juvenile Chinook salmon. A total of 32 sites (see Fig. 1) were sampled monthly between April and October 2003. The 13 Skagit Bay sites were also sampled monthly in August and September of 2002. Fish were collected by a $3.1 \times 6.1 \mathrm{~m}$ Kodiak surface trawl, or 'townet,' deployed between 2 boats, each with a $15.2 \mathrm{~m}$ tow line connected to a bridle on the net. The net was towed at the surface for 10 min per tow at a typical towing speed of approx. 2 knots. Three tows (2002 sampling) or 2 tows (2003 sampling) were performed for each monthly sampling at each site. Water depth, temperature and salinity were recorded for each tow.

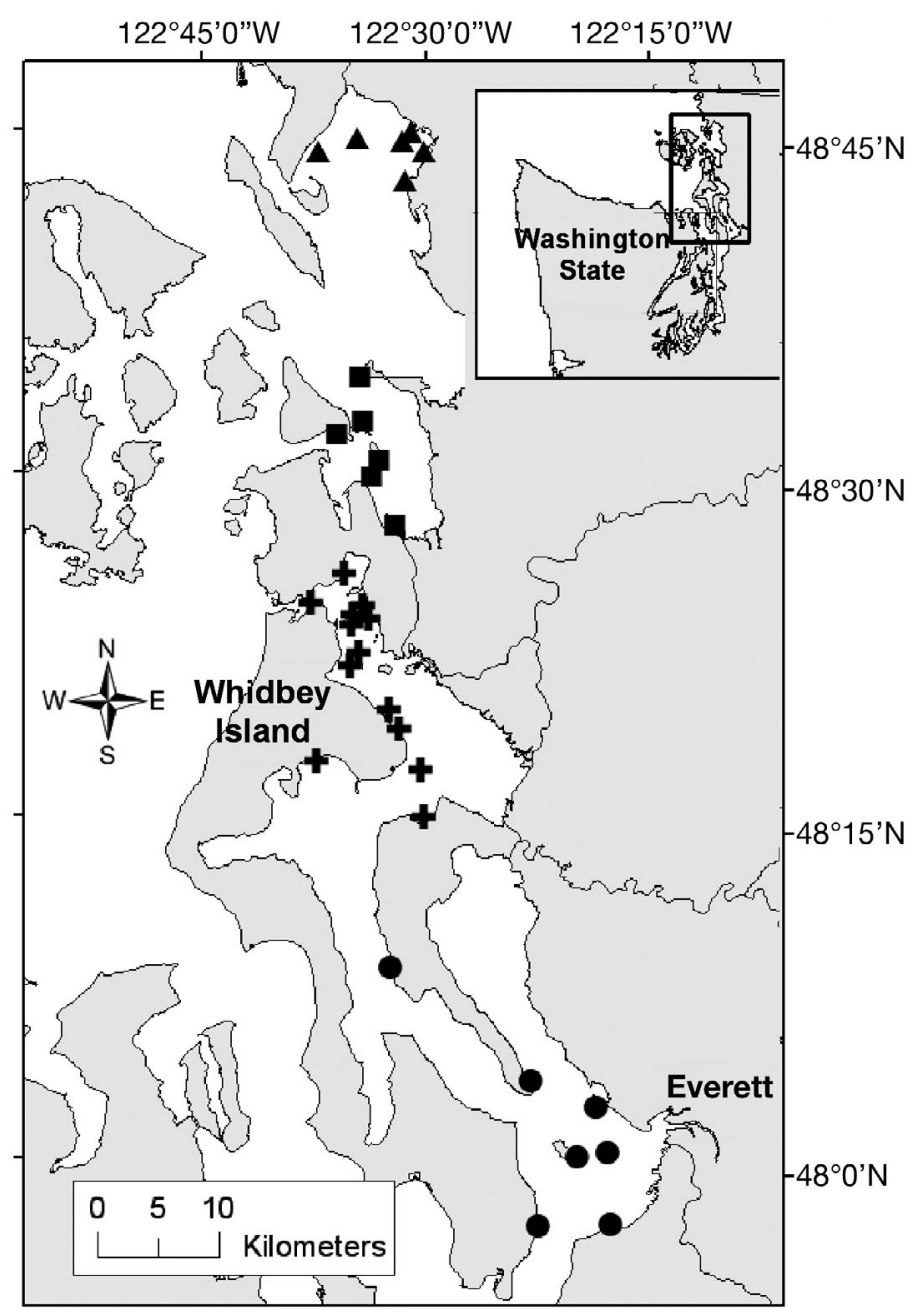

Fig. 1. North Puget Sound embayments and respective fish capture: Bellingham Bay (ム), Padilla Bay (ם), Skagit Bay (†), Possession Sound $(\boldsymbol{\theta})$ 
Total number and mass of Chinook salmon collected in each tow were recorded.

Up to 10 unmarked and 10 marked (adipose fin clipped or CWT) Chinook salmon were collected for each monthly sampling at each site. The non-hatchery Chinook salmon in the sampling areas are considered to be from endangered stocks of salmon, and the legal permissible capture limit was set at 10 per site per month. The hatchery fish sampling effort was matched to the wild fish sampling effort. Sampled fish were killed by cervical severance and branchial vessel exsanguination, examined for clipped fins, scanned for coded-wire tags with a wand type tag detector (Northwest Marine Technology) and measured for fork length. Coded-wire tags were recovered and read, and tag information was compared with the Regional Mark Information System Coded-Wire Tag Database (Regional Mark Processing Center, Pacific States Marine Fisheries Commission, www.rmpc.org) to determine stock origin. Because the recapture sample sizes for tagged fish were inadequate to evaluate the effect of each hatchery source on the prevalence of infection, stock sources were classified according to the embayment the outmigrating smolts would initially enter. Fish emigrating from hatcheries located within the same watershed are assumed to experience the same estuarine and nearshore marine conditions. Classifying fish by the first embayment encountered allowed a larger sample size while retaining information about the life history conditions and fish origin. Therefore, tagged fish from Kendall Creek hatchery and Lummi Sea Ponds were assigned to Bellingham Bay; tagged fish from Samish hatchery were assigned to Padilla Bay; tagged fish from Marblemount hatchery were assigned to Skagit Bay; and tagged fish from the Tulalip hatchery, Wallace River hatchery, or Whitehorse Pond were assigned to Possession Sound.

The entire kidney was excised, placed in a WhirlPak bag (Nasco) and stored on ice until a qFAT slide was prepared by the method of Cvitanich (Cvitanich 2004). Briefly, tissue was homogenized without dilution, and a film of homogenate was applied to a glass slide. The film was air-dried, heat-fixed, and rinsed with xylene before staining with FITC-conjugated polyclonal goat-anti Renibacterium salmoninarum antibody (Kirkegaard and Perry). A total of 400 fields per slide were examined at $\times 1000$ by epifluorescent microscopy in a non-overlapping grid pattern. Only intact, labeled bacterial cells of the correct morphology were counted. Because equivalent screening effort was applied to each slide, the qFAT value was expressed as the total number of cells counted.

Comparison of qFAT and quantitative polymerase chain reaction (qPCR). The $\mathrm{qFAT}$ and $\mathrm{qPCR}$ were compared by parallel analyses of kidney tissue inocu- lated with broth cultures of ATCC type strain 33209. Cell densities of broth cultures were determined by the membrane fluorescent antibody method (Elliott \& Barila 1987), and 10-fold serial dilutions were prepared. Equal weight aliquots of kidney tissue that were determined to be free of Renibacterium salmoninarum (Rhodes et al. 1998) were inoculated with the serial dilutions, and each inoculated tissue sample was divided into 2 aliquots. One aliquot was processed for qFAT as described above, and the other aliquot was subjected to DNA extraction with the DNeasy Kit (Qiagen) with the following modifications. Kidney tissue (25 mg) was combined with $180 \mu \mathrm{l}$ of lysis buffer (20 mM Tris- $\mathrm{HCl}, \mathrm{pH} 8.0 ; 2$ mM EDTA; $1.2 \%$ Triton X$100 ; 20 \mathrm{mg} \mathrm{ml}^{-1}$ lysozyme) and incubated for at least $45 \mathrm{~min}$ at $37^{\circ} \mathrm{C}$. The kit's proteinase $\mathrm{K}$ solution $(25 \mu \mathrm{l})$ and buffer AL $(200 \mu \mathrm{l})$ were added to each sample, incubated $>12 \mathrm{~h}$ at $55^{\circ} \mathrm{C}$ and heated to $70^{\circ} \mathrm{C}$ for at least $30 \mathrm{~min}$. The manufacturer's protocol for Gram-positive bacteria was followed thereafter, and DNA was suspended in a final volume of $200 \mu \mathrm{l}$.

Quantitative PCR (qPCR) was performed using TaqMan chemistry (Applied Biosystems) and $5 \mu \mathrm{l}$ of extract from the tissue inoculation in a total volume of $25 \mu \mathrm{l}$. Each reaction was performed in duplicate. Primers (Integrated DNA Technologies) were ABCtransfor2 (5' CTAAACGATTTCCCGGTCAA 3') and ABCtransrev2 (5' GATTTTGCCTGCTGGTATTTCC $3^{\prime}$ ), and the probe (Applied Biosystems) was ABCtrans (5' FAMAAGCGCCAGCAGTCGACGGC-TAMRA 3'). Reactions were performed and analyzed by an ABI 7700 (Applied Biosystems) under the following conditions: $50^{\circ} \mathrm{C}$ for $2 \mathrm{~min} ; 95^{\circ} \mathrm{C}$ for $10 \mathrm{~min} ; 45$ cycles of $95^{\circ} \mathrm{C}$ for $15 \mathrm{~s}$ and $60^{\circ} \mathrm{C}$ for $1 \mathrm{~min}$. Each plate included triplicate standard curve reactions of 7 dilutions of $R$. salmoninarum genomic DNA and no template control.

Data management and statistical analyses. Infection severity was analyzed by nonparametric tests due to non-normal data distribution. Prevalence of infection was initially assessed with univariate regression or contingency table analysis with the following factors: individual fish fork length; presence or absence of hatchery marking; location of capture; month of capture; stock origin; water temperature; salinity and depth at tow site. Due to the low number of fish examined in April and May (28 fish), these fish were excluded from regression analyses. In the analyses of infections among CWT fish, the fish collected in Skagit Bay and Possession Sound were combined because of the low number of fish from Possession Sound (19 fish). Using step-wise regression, we identified terms with moderate to strong associations. Iterative model assessment was then used to identify candidate models. Only variables with Chi-square probabilities for the parameter estimate and Wald test chi-square prob- 
abilities $<0.05$ were included in candidate models. Akaike's Information Criterion (AIC) was employed to compare candidate models and determine the optimal models (Burnham \& Anderson 2002).

\section{RESULTS}

\section{Relative sensitivity of qFAT and qPCR to detect Renibacterium salmoninarum}

To determine the relative sensitivity of qFAT to qPCR in detecting Renibacterium salmoninarum in infected tissues, kidney tissue free of infection was inoculated with serial dilutions of known concentrations of ATCC type strain 33209 broth cultures, and parallel aliquots of each inoculation were processed for analysis by each detection procedure. Three independent experiments were performed to compare the 2 detection methods. The sensitivity of qPCR was consistently high, ranging between 2 and 4 cells $\mathrm{mg}^{-1}$ of tissue (Fig. 2). Linear regressions of DNA detected by qPCR (in pg) to inoculation dose were highly significant $(\mathrm{p}<0.0001)$, with $\mathrm{r}^{2}$ values ranging between 0.989 and 0.999. The sensitivity of the qFAT method was slightly lower and more variable, ranging between 3 and 27 cells $\mathrm{mg}^{-1}$ of tissue, and the $\mathrm{r}^{2}$ values for linear regression of qFAT cell count to inoculation dose ranged between 0.982 and 0.997 . As a conservative estimate, the sensitivity of the qFAT is approx. 10-fold less than the sensitivity of qPCR.

\section{Prevalence of infection by Renibacterium salmoninarum}

The sites sampled in North Puget Sound (Fig. 1) were grouped into 4 principal geographic regions:

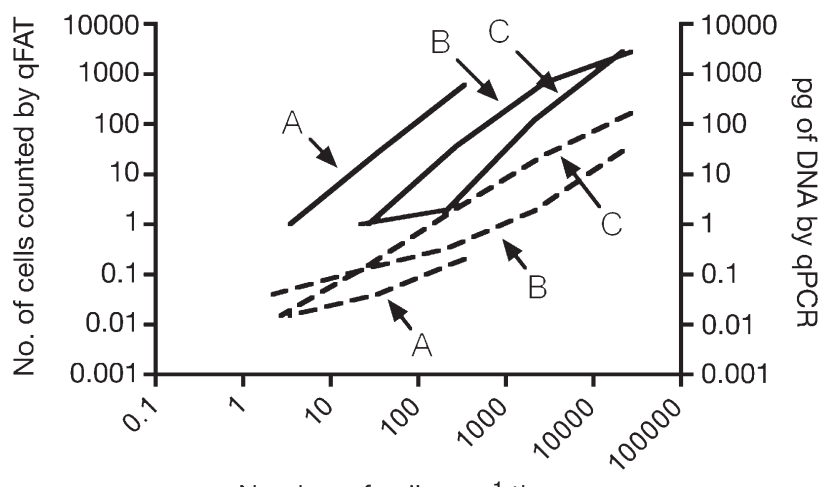

Number of cells $\mathrm{mg}^{-1}$ tissue

Fig. 2. Comparison of bacterial detection by qFAT (solid lines) and qPCR (dashed lines) of controlled tissue inoculations from 3 independent experiments $(A, B, C)$

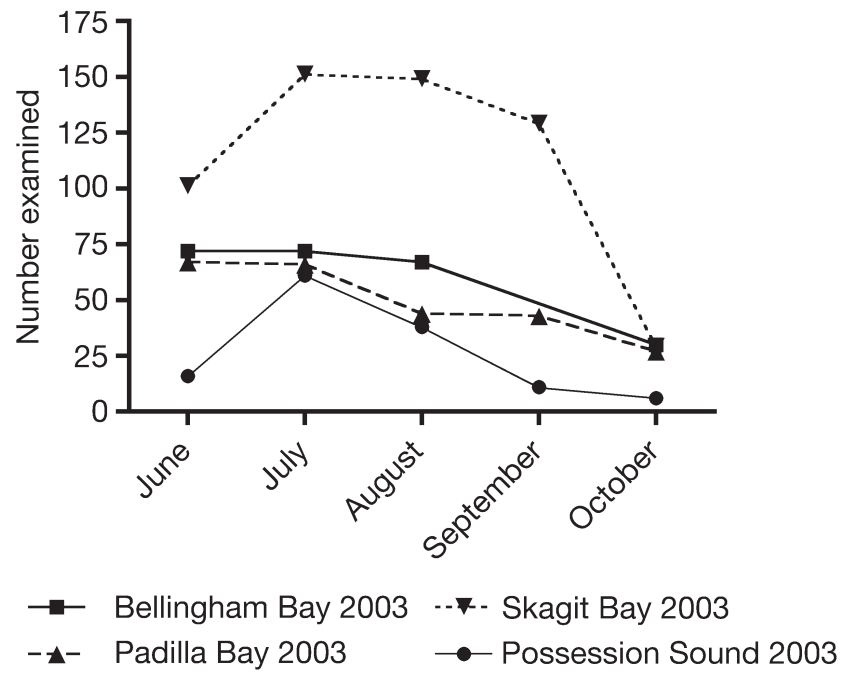

Fig. 3. Oncorhynchus tshawytscha. Total number of fish examined each month from 4 North Puget Sound embayments

Bellingham Bay (6 sites); Padilla Bay (6 sites); Skagit Bay (13 sites); and Possession Sound (8 sites). Although sampling efforts were made from April through October, only 1 fish was captured in April, and fewer than 6 fish per bay were captured during May. Due to equipment failure, no Bellingham Bay sites were sampled in September 2003. The number of fish sampled from June to October in 2003 varied among the bays and by month (Fig. 3). In 2002 and 2003, a total of 1480 juvenile Chinook salmon were sampled for qFAT analysis; 273 were sampled in 2002 (Skagit Bay only, during August and September) and 1207 were sampled in 2003 (all sites from April to October).

\section{Geographic patterns of infection}

A total of 247 fish (72 marked and 175 unmarked) from Bellingham Bay were captured, and this population had the highest prevalence of infection of any region. The percentages of infected fish were $63.9 \%$ $(95 \% \mathrm{CI}=52.3-74.0 \%)$ and $63.4 \%(95 \% \mathrm{CI}=$ $56.1-70.2 \%$ ) for marked and unmarked fish, respectively (Fig. 4). The 247 fish (95 marked and 152 unmarked) from Padilla Bay exhibited prevalences of $19.0 \%(95 \% \mathrm{CI}=12.4-28.0 \%)$ among marked fish and $27.6 \%$ (95\% CI $=21.1-35.2 \%)$ among unmarked fish. In Possession Sound, 122 fish (63 marked and 59 unmarked) were examined and the prevalences of infection were $17.5 \%(95 \%$ CI $=10.1-28.7 \%)$ for marked and $23.7 \%(95 \%$ CI $=14.7-36.0 \%)$ for unmarked fish.

Fish from Skagit Bay (273 captured in 2002; 560 in 2003) had the lowest prevalence of infection of any region. Prevalences for marked fish in 2002 were 


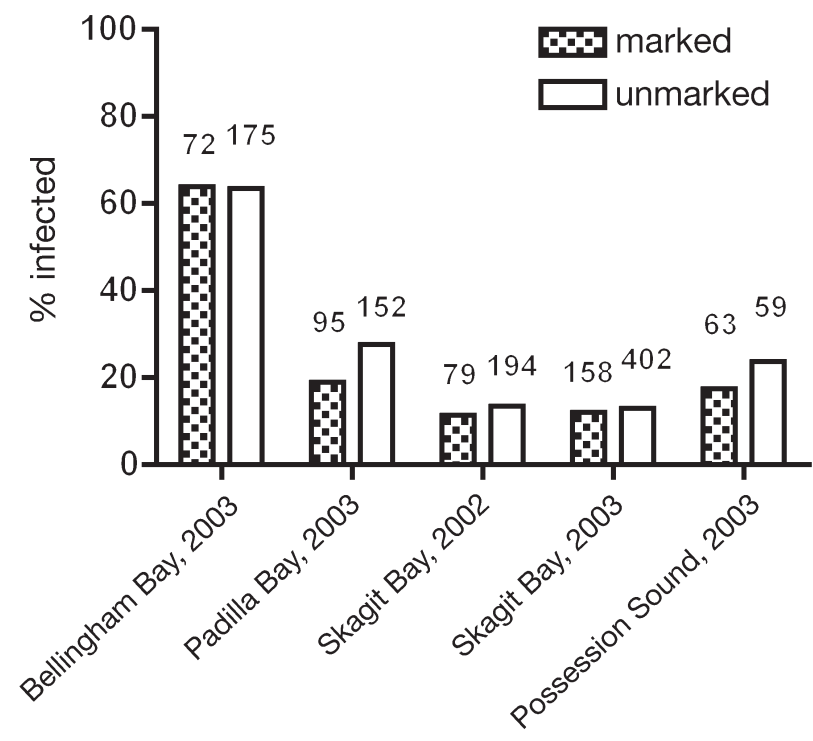

Fig. 4. Oncorhynchus tshawytscha. Prevalences of Renibacterium salmoninarum infection in marked and unmarked fish from 4 North Puget Sound embayments. Number of fish examined is at the top of each bar

$11.4 \%(95 \% \mathrm{CI}=6.2-20.3 \%)(79 \mathrm{fish})$ and $12.0 \%(95 \%$ $\mathrm{CI}=7.9-18.0 \%$ ) in 2003 (158 fish); prevalences for unmarked fish in 2002 were $13.5 \%(95 \% \mathrm{CI}=9.3-18.9 \%)$ (194 fish) and 12.9\% (10.0-16.6\%) in 2003 (402 fish).

\section{Prevalence of infection in CWT fish}

For fish originating from Skagit Bay sources and captured in Skagit Bay in 2002 and 2003, the percentages of infected fish ranged between $9 \%$ and $11 \%$, with an average of $10.2 \%$ (Table 1). Fish from other sources that were captured in Skagit Bay had a wider range of prevalences of infection ranging from 0 to $15 \%$. Surprisingly, prevalences of infection for fish captured in Bellingham Bay were high regardless of stock origin (Table 1). The pattern in Padilla Bay was mixed; fish from Padilla Bay and Bellingham Bay stocks exhibited lower prevalences (11.1\% and $14.3 \%$, respectively), while fish from the Skagit stocks displayed a moderate level of prevalence (35.3\%). Few fish originating from the other embayments were captured in Possession Sound, where prevalences were low.

Marked fish were assumed to be of hatchery origin, and CWT fish were unequivocally of hatchery origin. The absence of differences in prevalence between the marked fish without CWT and the CWT fish at each of the capture sites would support the assumption that both types of marked fish may be combined into a single group to represent hatchery fish (Table 1). Using contingency table comparisons between marked fish with and without CWT, we found that the proportions of infected fish from each bay were not different (Fishers exact test, p >0.1), suggesting that the prevalences of infection for marked fish are good estimates for hatchery fish.

\section{Temporal patterns of infection}

The prevalence of infection varied temporally among the 4 bays (Fig. 5), and no consistent pattern was observed across the bays. Prevalences in Bellingham Bay peaked in July, followed by a decline through October, while prevalences in Padilla Bay increased from June through September. Prevalences in Skagit Bay and Possession Sound displayed parallel fluctuations from June through September. (Because the October sample for Possession Sound consisted of only 6 fish, the prevalence is not shown.)

Fork length for all examined fish was recorded, and lengths were aggregated by month of capture for each embayment (Fig. 6) or by marking (Fig. 7). Regardless of the month of capture, fish median fork lengths from Possession Sound were greater than those from all other embayments. Fish collected in May were larger than fish collected in June from the same embayments (data not shown), and from June through October, median fork length increased monotonically at all 4 embayments. These results suggest that most of the fish collected in May were early migrating yearlings, while

Table 1. Prevalence of Renibacterium salmoninarum infection among fish with coded wire tags (CWT) by capture site and stock origin and among marked fish without CWT by capture site. Number of fish examined is in parentheses

\begin{tabular}{|lcccc|}
\hline \multirow{2}{*}{ Stock origin } & \multicolumn{4}{c|}{ Capture site } \\
\cline { 2 - 5 } & $\begin{array}{c}\text { Bellingham } \\
\text { Bay }\end{array}$ & $\begin{array}{c}\text { Padilla } \\
\text { Bay }\end{array}$ & $\begin{array}{c}\text { Skagit } \\
\text { Bay }\end{array}$ & $\begin{array}{c}\text { Possession } \\
\text { Sound }\end{array}$ \\
\hline Bellingham Bay & $83.3 \%$ & $14.3 \%$ & $10.0 \%$ & $0 \%$ \\
& $(24)$ & $(7)$ & $(10)$ & $(1)$ \\
Padilla Bay & $50.0 \%$ & $11.1 \%$ & $0 \%$ & \\
& $(2)$ & $(9)$ & $(8)$ & $(0)$ \\
Skagit Bay & $59.1 \%$ & $35.3 \%$ & $10.2 \%$ & $25.0 \%$ \\
& $(22)$ & $(17)$ & $(98)$ & $(4)$ \\
Possession Sound & $(0)$ & $(0)$ & $15.0 \%$ & $14.3 \%$ \\
& $70.8 \%$ & $24.2 \%$ & $10.3 \%$ & $15 \%$ \\
Total (CWT fish) & $(48)$ & $(33)$ & $(136)$ & $(19)$ \\
& $50.0 \%$ & $16.1 \%$ & $13.9 \%$ & $19.5 \%$ \\
Total (marked, no CWT) & $(24)$ & $(62)$ & $(101)$ & $(41)$ \\
& & & & \\
\end{tabular}



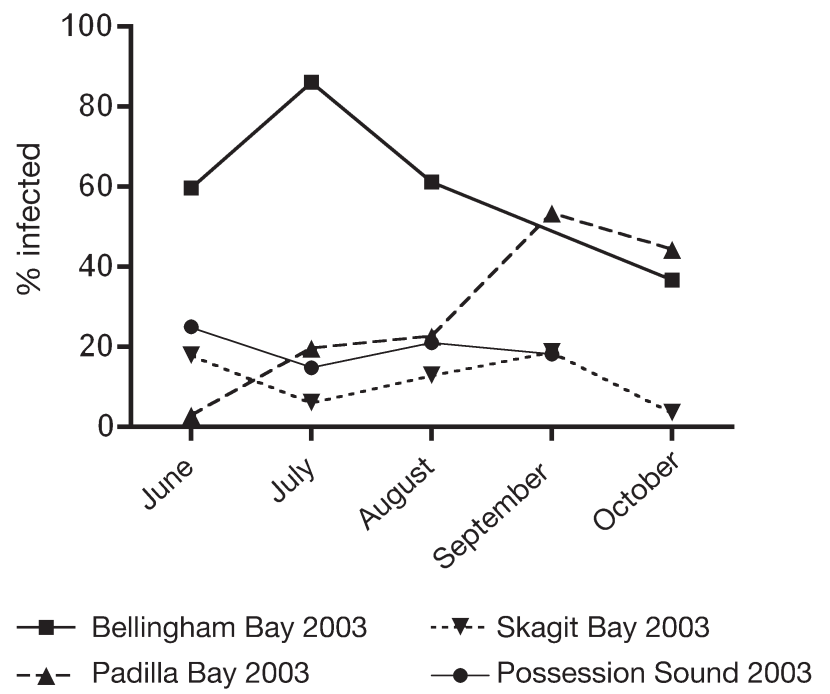

Fig. 5. Oncorhynchus tshawytscha. Overall prevalence of Renibacterium salmoninarum infection by month from 4 North Puget Sound embayments. The October sample for Possession Sound consisted of 6 fish and is not included in the graph

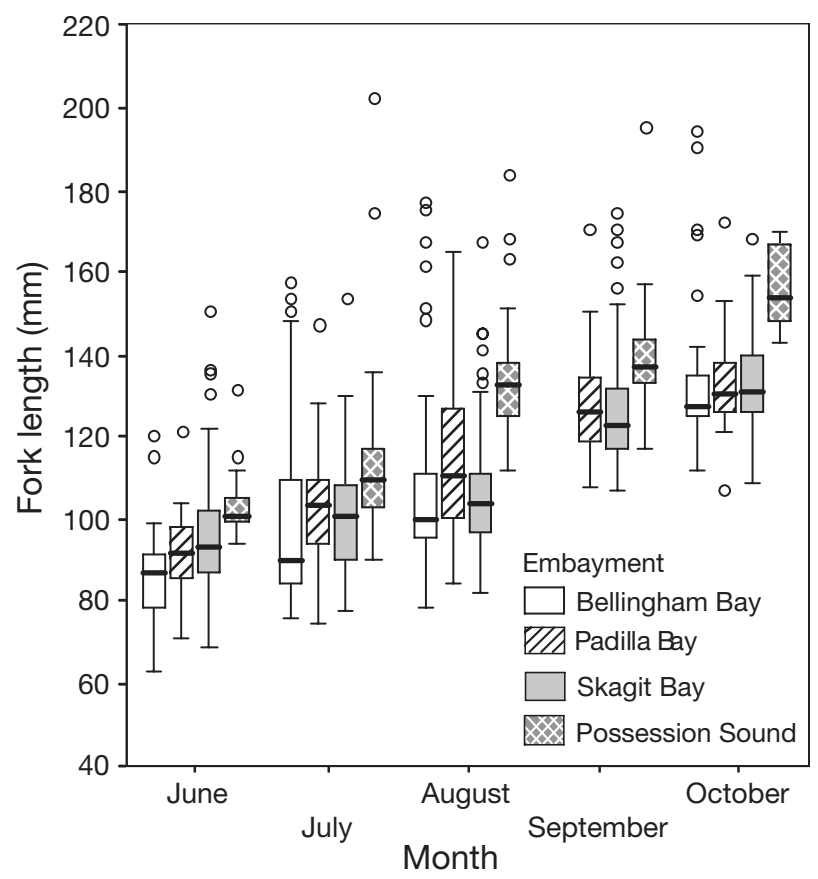

Fig. 6. Oncorhynchus tshawytscha. Box plots of fork lengths (mm) of examined fish for each month by embayment

most of those collected from June through October were subyearlings. From July through October, median fork lengths of marked fish were greater than that of unmarked fish. In spite of the differences in median fork lengths among embayments, by marking and by month, no relationship between prevalence of infection and length was apparent.

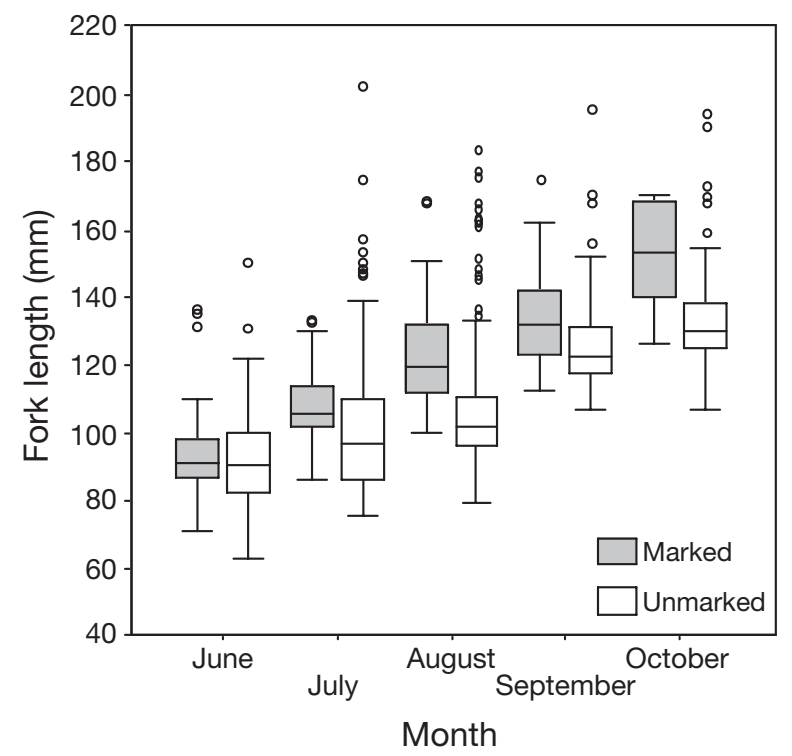

Fig. 7. Oncorhynchus tshawytscha. Box plots of fork lengths (mm) of examined fish for each month by marking

Logistic regression modeling of prevalences

Logistic regression modeling was applied to the prevalence of Renibacterium salmoninarum infection data to assess the contribution of individual, temporal and geographic variables (fish fork length, presence or absence of marking, month of capture, bay of capture) and environmental variables (water depth, salinity and temperature at tow site). Fish fork length, fish marking and water depth consistently failed to significantly contribute to univariate regression models $(\mathrm{p}>0.05, \mathrm{~N}=$ 1448). For an overall proportion of 0.26 with the odds at $1 \mathrm{SD}$ above the mean for dichotomous parameters (e.g. 0.8 for hatchery marking), and 1-tailed $\alpha=0.05$, the power of the regression was 0.95 . For continuous covariates with odds closer to 1 (e.g. water depth), sample sizes would have needed to be more than quadrupled $(\mathrm{N}>5800)$ for power $=0.95$, indicating that an inadequate sample size was not the basis of non-significance. Fish length, marking and water depth also failed to significantly contribute to multivariate models, suggesting that these variables did not affect the probability of infection by $R$. salmoninarum, and these variables were not included in the final model analysis.

For infection probability among all fish examined, 4 candidate models were compared by AIC (Table 2). Model 4, which included the variables bay of capture, month of capture, salinity and temperature, was determined to be the best model from minimum AIC (Table 3). Based on this model, fish captured in Bellingham Bay were more likely to be infected than fish captured at the other 3 bays, and infection probability was 
lower in June than during other capture months. Furthermore, the probability of infection declined as water salinity and temperature increased at the capture site.

Prevalence of infection in CWT fish was analyzed separately by logistic regression, including an additional variable for stock origin. Using the optimal model for this subset, we found that fish captured in Bellingham Bay had a higher probability of infection than fish captured at the other bays (Table 4). In contrast to the model for all fish examined, probability of infection increased with increasing temperature and there was no effect of salinity on infection probability.

Table 2. Selection criteria summary of 4 logistic regression models for infection probability compared by Akaike's Information Criterion (AIC)

\begin{tabular}{|c|c|c|c|c|}
\hline Model & (wh & $\begin{array}{l}\text { Chi-square } \\
\text { probability } \\
\text { ole model test) }\end{array}$ & $\mathrm{r}^{2}$ for model & $\begin{array}{c}\text { AIC } \\
\text { difference }\end{array}$ \\
\hline 1 & Bay, temperature, salinity & $<0.0001$ & 0.1652 & 27.69468 \\
\hline 2 & $\begin{array}{l}\text { Bay, temperature, salinity, } \\
\text { temperature } \times \text { salinity }\end{array}$ & $<0.0001$ & 0.1696 & 23.88048 \\
\hline 3 & $\begin{array}{l}\text { Bay, temperature, salinity, } \\
\text { temperature } \times \text { salinity, mo }\end{array}$ & $\begin{array}{l}<0.0001 \\
\text { nth }\end{array}$ & 0.1927 & 0.67332 \\
\hline 4 & $\begin{array}{l}\text { Bay, temperature, salinity, } \\
\text { month }\end{array}$ & $<0.0001$ & 0.1918 & 0.00000 \\
\hline
\end{tabular}

\section{Severity of infection by Renibacterium salmoninarum}

Quantification by the qFAT method resulted in a total number of bacterial cells for each specimen. Because the microscopic screening effort was uniform among specimens, the qFAT number could be used as an assessment of the severity of the infection. This qFAT value ranged from 1 cell (37.4\% of the infected fish) to 1465 cells (1 fish). Among all infected fish, severity was low with $82.3 \%$ of the infected fish exhibiting 10 or fewer total number of cells (Fig. 8). Comparison of the qFAT values between all marked and all unmarked fish, regardless of season or embayment, revealed no significant difference ( $\mathrm{p}>0.05$, MannWhitney $U$-test). In contrast, the qFAT values among the 4 embayments were significantly different (Kruskal-Wallis, $\mathrm{p}<0.001)$. The numbers of Renibacterium salmoninarum cells counted per specimen were significantly higher among infected fish from Bellingham Bay than that for infected fish from Skagit or Padilla Bay (Dunn's Multiple Comparison, $p<0.001)$, whereas the qFAT values for Skagit Bay, Padilla Bay and Possession Sound were not significantly different (Dunn's Multiple Comparison, $\mathrm{p}>0.05$ ).

Table 3. Parameter estimates with significance and effect for variables included in optimal logistic regression model of prevalence of infection $(\mathrm{N}=1146)$

\begin{tabular}{|c|c|c|c|c|}
\hline $\begin{array}{l}\text { Parameter } \\
\text { term }\end{array}$ & $\begin{array}{l}\text { Estimate } \\
\text { (SE) }\end{array}$ & $\begin{array}{l}\text { Chi-square } \\
\text { probability } \\
\text { of estimate }\end{array}$ & $\begin{array}{c}\text { Odds ratio } \\
( \pm 95 \% \text { confidence } \\
\text { interval) }\end{array}$ & $\begin{array}{l}\text { Significance and } \\
\text { effect of parameter } \\
\text { term on prevalence }\end{array}$ \\
\hline \multicolumn{5}{|l|}{ Bay: } \\
\hline Bellingham Bay & $\begin{array}{l}1.55117727 \\
(0.1689955)\end{array}$ & $<0.0001$ & $\begin{array}{c}22.250 \\
(11.578-43.604)\end{array}$ & $\begin{array}{l}\text { Highly significant; } \\
\text { positive effect }\end{array}$ \\
\hline Padilla Bay & $\begin{array}{l}-0.0767757 \\
(0.1505884)\end{array}$ & 0.6102 & $\begin{array}{c}0.858 \\
(0.473-1.542)\end{array}$ & Not significant \\
\hline Possession Sound & $\begin{array}{l}-0.1203634 \\
(0.1931815)\end{array}$ & 0.5332 & $\begin{array}{c}0.786 \\
(0.361-1.649)\end{array}$ & Not significant \\
\hline Salinity & $\begin{array}{l}-0.0791568 \\
(0.0180551)\end{array}$ & $<0.0001$ & $\begin{array}{c}0.094 \\
(0.033-0.273)\end{array}$ & $\begin{array}{l}\text { Highly significant; } \\
\text { negative effect }\end{array}$ \\
\hline Temperature & $\begin{array}{l}-0.1174379 \\
(0.0579192)\end{array}$ & 0.0426 & $\begin{array}{c}0.335 \\
(0.115-0.954)\end{array}$ & Significant; negative effect \\
\hline \multicolumn{5}{|l|}{ Month: } \\
\hline June & $\begin{array}{l}-0.8769576 \\
(0.2000419)\end{array}$ & $<0.0001$ & $\begin{array}{c}0.173 \\
(0.078-0.374)\end{array}$ & $\begin{array}{l}\text { Highly significant; } \\
\text { negative effect }\end{array}$ \\
\hline July & $\begin{array}{l}0.14014338 \\
(0.1597614)\end{array}$ & 0.3804 & $\begin{array}{c}1.324 \\
(0.704-2.468)\end{array}$ & Not significant \\
\hline August & $\begin{array}{l}-0.0548094 \\
(0.1577149)\end{array}$ & 0.7282 & $\begin{array}{c}0.896 \\
(0.480-1.657)\end{array}$ & Not significant \\
\hline October & $\begin{array}{l}-0.1379355 \\
(0.2483529)\end{array}$ & 0.5786 & $\begin{array}{c}0.759 \\
(0.281-1.978)\end{array}$ & Not significant \\
\hline
\end{tabular}


Table 4. Parameter estimates with significance and effect for variables included in optimal logistic regression model of prevalence of infection among coded-wire tag fish that were identified for stock origin $(\mathrm{N}=187)$

\begin{tabular}{|c|c|c|c|c|}
\hline Parameter term & $\begin{array}{c}\text { Estimate } \\
\quad(\mathrm{SE})\end{array}$ & $\begin{array}{l}\text { Chi-square } \\
\text { probability } \\
\text { of estimate }\end{array}$ & $\begin{array}{c}\text { Odds ratio } \\
\text { ( } \pm 95 \% \text { confidence } \\
\text { interval) }\end{array}$ & $\begin{array}{l}\text { Significance and effect } \\
\text { of parameter term on prevalence }\end{array}$ \\
\hline \multicolumn{5}{|l|}{ Bay: } \\
\hline Bellingham Bay & $\begin{array}{l}1.13841726 \\
(0.312013)\end{array}$ & 0.0003 & $\begin{array}{c}9.745 \\
(2.923-34.286)\end{array}$ & Highly significant; positive effect \\
\hline Padilla Bay & $\begin{array}{l}-0.2345847 \\
(0.3178979)\end{array}$ & 0.4606 & $\begin{array}{c}0.626 \\
(0.169-2.101)\end{array}$ & Not significant \\
\hline Temperature & $\begin{array}{l}0.27763297 \\
(0.0994162)\end{array}$ & 0.0052 & $\begin{array}{c}12.509 \\
(2.128-76.313)\end{array}$ & Highly significant; positive effect \\
\hline
\end{tabular}

\section{Physical characteristics at capture sites}

Seasonal patterns in water temperature and salinity were similar among the bays, but there were differences in the monthly averages (Figs. 9 \& 10). Highest average temperatures were observed in July for all embayments except Skagit Bay, where the average water temperature was highest in August. Lowest average water temperatures for all embayments occurred during the October sampling. Possession Sound exhibited the widest range of average water temperatures $\left(5.9^{\circ} \mathrm{C}\right)$, while Skagit Bay had the narrowest average water temperature range $\left(2.4^{\circ} \mathrm{C}\right)$. Bellingham Bay consistently displayed the highest temperatures of all embayments and Skagit Bay temperatures were the lowest. Average salinity increased throughout the 2003 sampling period in all the em- bayments, with only Possession Sound exhibiting a decline during October. However, from June through August, average salinity in Bellingham Bay was considerably lower than all other bays.

\section{DISCUSSION}

The principal goal of this study was to assess the likelihood of infection among hatchery and natural origin juvenile Chinook salmon early after outmigration. We found that the location of capture, rather than the stock origin, was a strong predictor of the probability of infection. Furthermore, there was no difference in prevalences between marked (hatchery) and unmarked (presumptive natural origin) juvenile fish from 4 embayments in northern Puget Sound, suggesting

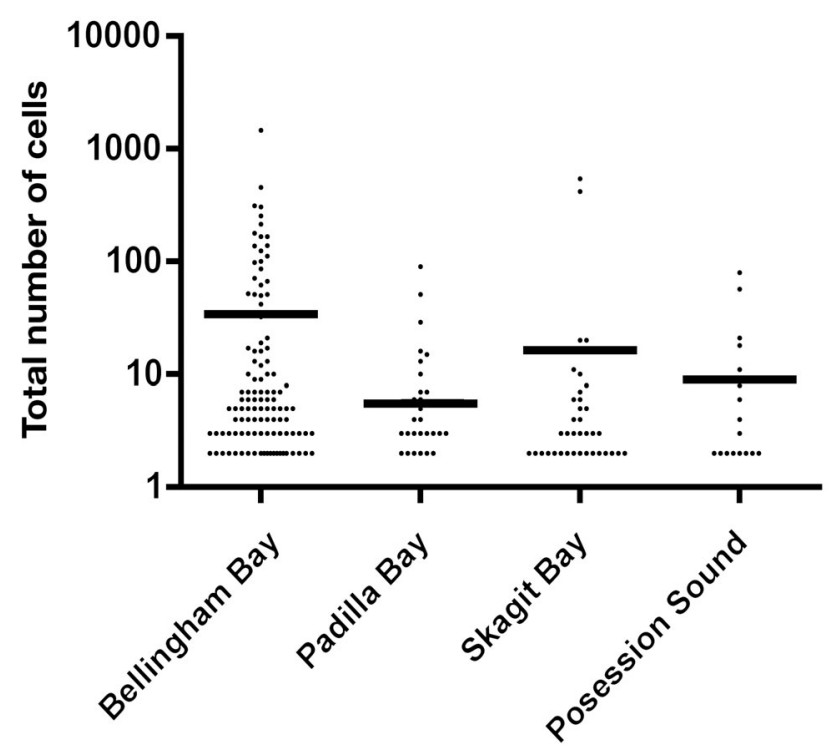

Fig. 8. Oncorhynchus tshawytscha. Scatterplot of number of Renibacterium salmoninarum cells counted per infected fish by capture location. Thick horizontal bars show mean
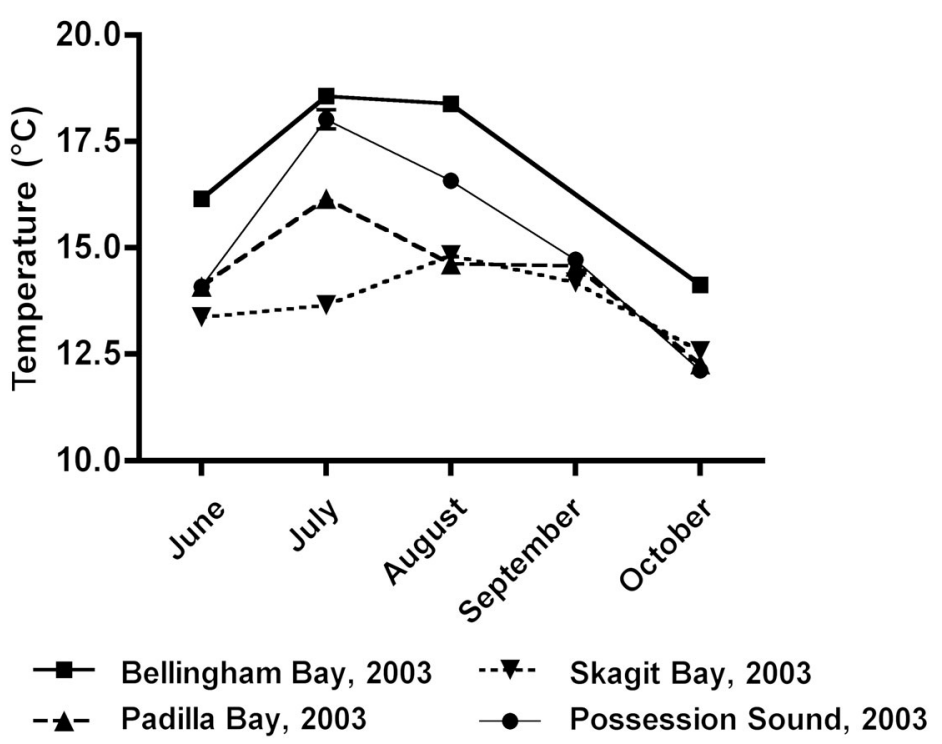

Fig. 9. Average water temperatures $\left({ }^{\circ} \mathrm{C} \pm \mathrm{SEM}\right)$ at time of trawl effort by month. Due to equipment failure, no trawling occurred in Bellingham Bay during September 


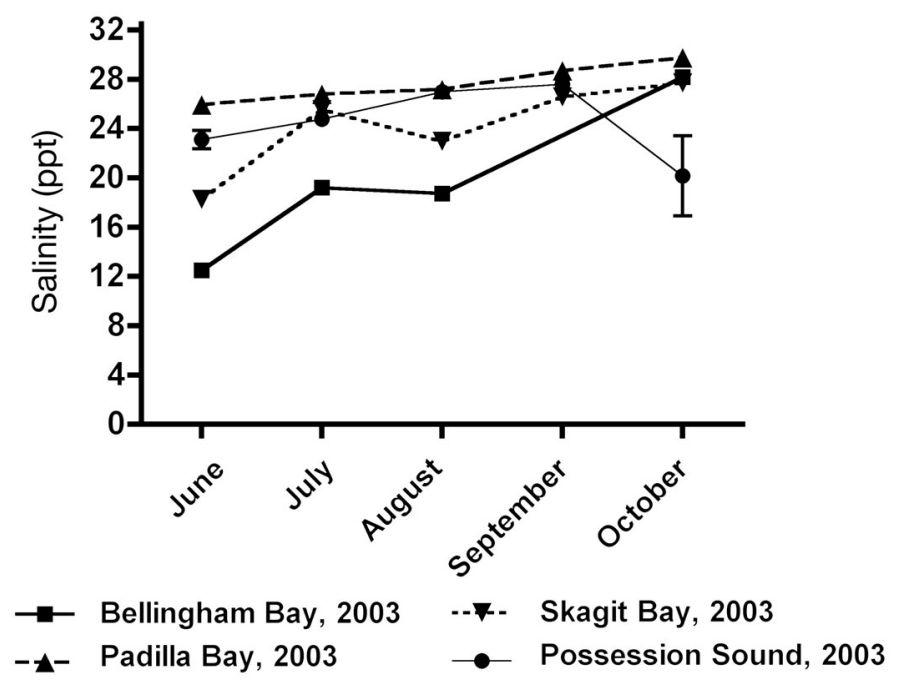

Fig. 10. Average water salinity (ppt \pm SEM) during trawls by month. Due to equipment failure, no trawling occurred in Bellingham Bay during September

that populations within a bay have homogeneous probabilities of infection. Environmental factors, such as water temperature and salinity and the month of capture were also significant influences on infection probability. Taken together, these results indicate that infection probability depends on physical proximity and physical conditions.

Fish collected from Bellingham Bay were 5 to 6 times more likely to be infected than fish from the other 3 bays, and infected fish from Bellingham Bay bore a higher bacterial burden in the kidney than fish from the other bays (Fig. 8). This association with Bellingham Bay, rather than stock origin, could be due to one or more possible causes. Fish from a cryptically infected (i.e. below the qFAT detection limit) stock may migrate into environmental conditions that induce infection to a detectable level. Salinities in Bellingham Bay were significantly lower than all other bays, and the lower salinities could serve as an environmental stressor. However, Renibacterium salmoninaruminfected Chinook salmon are surprisingly resilient to a range of stressors (Mesa et al. 2000). Alternatively, infected fish may exhibit a behavioral orientation for certain environmental conditions. For example, if afflicted fish display a preference for lower salinity water (Seals Price \& Schreck 2003), infected Skagit stock fish may migrate from Skagit Bay to Bellingham Bay. However, the simplest explanation is that the observed infections were acquired by horizontal transmission after migration to the capture location.

Management plans for the major fish rearing facilities that release fish to our sampling sites have formal disease control and reduction policies and procedures.
These include culling eggs of diseased broodstock, segregation of broodstock, removal of diseased fry and antibiotic treatment (Washington State Department of Fish and Wildlife 2005). Despite the selective pressure to reduce disease in released (marked) fish, there was no significant difference in prevalences of infection between marked and unmarked fish for each embayment, and logistic regression modeling consistently failed to identify marking as an important factor in predicting the likelihood of infection. The failure to observe lower prevalences among the marked fish may be a result of one or more of the following possibilities.

(1) Pathogen control and reduction methods employed at the hatchery may not effectively reduce infection in released fish. Although the source hatcheries for the CWT fish in this study were not able to offer data on the infection status of the released fish, all employ procedures to reduce infection, such as injection of broodstock with antibiotics prior to spawning, culling of eggs from broodstock with elevated levels of bacterial antigens in kidney tissue, and destruction of diseased fry (Washington State Department of Fish and Wildlife 2005). The disease reduction measures used by hatcheries contributing to the areas under study have demonstrated effectiveness under hatchery conditions (Brown et al. 1990, Pascho et al. 1991, Elliott et al. 1995, Gudmundsdottir et al. 2000), although variations in implementation could affect the outcome. A comparison of marked and unmarked outmigrating Chinook salmon in the Columbia and Snake Rivers from hatcheries utilizing BKD management practices observed significantly higher prevalences of Renibacterium salmoninarum in unmarked fish (Elliott et al. 1997), suggesting that certain disease control practices can have demonstrable effects on the released population. The design of the present study did not rely on knowledge of infection status of released fish, and the absence of this information does not affect the conclusions.

(2) Environmental stressors, including the physiological rigors of outmigration and water quality parameters, could exert a strong selective pressure that masks the effects of disease management practices or could result in uniform prevalences between marked and unmarked fish. Infected fish may have a poorer survival prognosis during down-river migration (Pascho et al. 1993) and transition to seawater (Sanders et al. 1992, Moles 1997), and infection can adversely affect critical physiological processes (Mesa et al. 1999). Hatchery fish display differential migration patterns in marine habitats (Levings et al. 1986), and the impact of infection, if any, on this behavior could underlie the observed prevalences among marked fish.

(3) A reservoir for Renibacterium salmoninarum infection could present a uniform source of contagion for both marked and unmarked fish. Potential reservoirs 
include salmonids other than Chinook salmon, nonsalmonid fish (Mitchum \& Sherman 1981, Meyers et al. 1993, Kent et al. 1998, Nagai \& Iida 2002), and even bivalves (Starliper \& Morrison 2000).

(4) Marking efficiencies at hatcheries may vary, resulting in sizeable numbers of unmarked fish that are actually of hatchery origin. Although the 2002 hatchery management plans indicate that all released fish were to be marked (Washington State Department of Fish and Wildlife 2005), the percentage of unmarked fish released is not indicated. Marking efficiencies are expected to be high, because they are used to estimate impacts on native stocks of escapement of hatchery fish into rivers at spawning and for broodstock selection, which are critical issues for preservation and restoration of endangered Chinook salmon stocks in Puget Sound. We found that prevalence patterns between marked fish with and without CWT were indistinguishable, indicating that the survey of marked fish was representative of hatchery fish. There is no comparable method of confidently identifying unmarked fish as natural spawn fish, and our assignment relies on good hatchery marking efficiencies.

(5) Interactions between marked and unmarked fish might occur, resulting in pathogen transmission and equivalent infection prevalences. Infected Chinook salmon shed bacteria (Balfry et al. 1996, McKibben \& Pascho 1999), and planktonic Renibacterium salmoninarum can persist in seawater up to $14 \mathrm{~d}$ (Balfry et al. 1996). Laboratory comparisons of exposure by immersion in suspensions of $R$. salmoninarum or by cohabitation of infected fish have shown that the latter exposure method is the more effective method of horizontal transmission (Murray et al. 1992). Uptake of $R$. salmoninarum may occur through ingestion of contaminated fecal material or water, epithelial adsorption and external abrasions (Hendricks \& Leek 1975, Evenden et al. 1993, Balfry et al. 1996), although gill epithelia may not be an important route of entry (McIntosh et al. 2000). Vertical transmission of $R$. salmoninarum can also be a source of infection. Broodstock that spawn naturally, whether wild or hatchery in origin, contribute progeny to the unmarked juvenile population. Consequently, the proportion of juvenile fish collected by surface trawl that are $F_{1}$ progeny from released hatchery fish depends upon the level of escapement in returning hatchery fish.

There was a striking difference in the effects of water temperature and salinity between the optimal regression models for all fish examined (Table 3) and the subset of CWT fish (Table 4). Because spatial and temporal differences in migration into the nearshore areas by hatchery and natural spawning fish have been observed in other aspects of this study (C. Rice unpubl. data), the temperature and salinity distribu- tions for the CWT fish are not likely to be representative of the distributions for all fish sampled. Furthermore, temperature and salinity may have more complex associations with prevalence of infection than indicated by the regression models. For example, coho salmon smolts with clinical BKD exhibited poor survival with abrupt seawater challenge, whereas acclimation with low salinity water before seawater challenge dramatically improved survival (Moles 1997).

To assess and quantify Renibacterium salmoninarum infection levels, we chose to use qFAT for several reasons. First, tissue collection did not always permit tool treatment for DNA removal, a necessary step in reducing cross-contamination for PCR-based detection. Second, the qFAT method employs both a specific reagent (polyclonal anti- $R$. salmoninarum antibody) and cell morphology for identification, reducing the risk of false positives. Finally, qFAT sensitivity approaches that of qPCR, a highly sensitive and quantitative detection method. In 3 independent experiments, under controlled inoculation experiments using sterile kidney tissue, qFAT detected $\leq 30$ cells $\mathrm{mg}^{-1}$ of tissue, while qPCR detected 2 to 3 cells $\mathrm{mg}^{-1}$ of tissue. Detection by an ELISA, which is currently the most widely used method, is not linearly associated with bacterial burden (Hamel \& Anderson 2002), limiting the utility of the ELISA for low bacterial burdens expected in chronic or subclinical infections. Because a standard number of fields are examined, qFAT can provide a quantitative estimate of bacterial burden. Thus, qFAT is an accurate, reliable detection method for samples collected under suboptimal conditions that are typical of field conditions.

In summary, we have assessed the prevalence of Renibacterium salmoninarum infection among juvenile Chinook salmon from nearshore marine habitats and found that infection probability was influenced by site of capture, month of capture, water salinity and temperature. Surprisingly, stock origin had no effect on infection probabilities. There were no differences in prevalences between marked and unmarked fish throughout northern Puget Sound, suggesting a common reservoir of infection for hatchery and natural spawn fish. If there are considerable interactions among $R$. salmoninarum-infected free-ranging salmon, health practices by fish culture operations (e.g. egg planting, restorative fry releases, aquaculture) can have an impact on prevalences. Future studies on the prevalence of infection that encompass full life cycles of salmon should help determine whether infections in juvenile fish affect long-term survival.

Acknowledgements. The Northwest Fisheries Science Center (NWFSC) of the National Marine Fisheries Service (National Oceanic and Atmospheric Administration, US Department of 
Commerce) provided substantial logistic, personnel and analytical support. Staff from the United States Geological Survey's Western Fisheries Research Center assisted with sample collection, as did K. Fresh and A. Kagley from the Estuarine and Ocean Ecology Program (NWFSC). We are indebted to E. Beamer and R. Henderson (Skagit River System Cooperative) for sampling assistance and reading coded-wire tags, and to F. Sommers (NWFSC) for assistance in sample collection. C. Greene (NWFSC), O. Hamel (NWFSC) and S. Mumford (US Fish and Wildlife Service) provided thoughtful review and helpful insights to this manuscript. The NWFSC Internal Grants Program supported C.D. and S.L.N. The support for C.A.R. was by the Watershed Program (NWFSC), and L.D.R. was supported by the Integrative Fish Biology Program (NWFSC). Seattle City Light, US Army Corps of Engineers, Estuarine and Ocean Ecology Program and the Port of Bellingham provided supplemental funding. Mention of trade names or commercial products in this paper is solely for the purpose of providing specific information and does not imply recommendation or endorsement.

\section{LITERATURE CITED}

Anderson ED, Engelking HM, Emmenegger EJ, Kurath G (2000) Molecular epidemiology reveals emergence of a virulent infectious hematopoietic necrosis (IHN) virus strain in wild salmon and its transmission to hatchery fish. J Aquat Animal Health 12:85-99

Arkoosh MR, Clemons E, Kagley AN, Stafford C and 8 others (2004) Survey of pathogens in juvenile salmon Oncorhynchus spp. migrating through Pacific Northwest estuaries. J Aquat Animal Health 16:186-196

Balfry SK, Albright LJ, Evelyn TPT (1996) Horizontal transfer of Renibacterium salmoninarum among farmed salmonids via the fecal-oral route. Dis Aquat Org 25:1-2

Banner CR, Fryer JL, Rohovec JS (1986) Occurrence of salmonid fish infected with Renibacterium salmoninarum in the Pacific Ocean. J Fish Dis 9:273-275

Brooks KM (2005) The effects of water temperature, salinity and currents on the survival and distribution of the infective copepodid stage of sea lice Lepeophtheirus salmonis originating on Atlantic salmon farms in the Broughton Archipelago of British Columbia, Canada. Rev Fish Sci 13:177-204

Brown LL, Albright LJ, Evelyn TPT (1990) Control of vertical transmission of Renibacterium salmoninarum by injection of antibiotics into maturing female coho salmon Oncorhynchus kisutch. Dis Aquat Org 9:127-131

Burnham KP, Anderson DR (2002) Model selection and multimodal inference: A practical information-theoretic approach. 2nd edition, Vol. Springer-Verlag, New York

CFR (2005) Endangered and threatened species: final listing determinations for 16 ESUs of west coast salmon, and final 4(d) protective regulations for threatened salmonid ESUs. Code of Federal Regulations, Title 50, Parts 223-224 .p 37160-37204

Cvitanich JD (2004) Renibacterium salmoninarum bar forms: characterization, occurrence, and evidence of a host response to a $R$. salmoninarum infection. J Fish Dis 27: 193-211

Elliott DG, Barila TY (1987) Membrane filtration - fluorescent antibody staining procedure for detecting and quantifying Renibacterium salmoninarum in coelomic fluid of chinook salmon (Oncorhynchus tshawytscha). Can J Fish Aquat Sci 44:206-210

Elliott DG, Pascho RJ, Palmisano AN (1995) Brood stock segregation for the control of bacterial kidney disease can affect mortality of progeny chinook salmon (Oncorhynchus tshawsytscha) in seawater. Aquaculture 132:133-144

Elliott DG, Pascho RJ, Jackson LM, Matthews GM, Harmon JR (1997) Renibacterium salmoninarum in spring-summer chinook salmon smolts at dams on the Columbia and Snake Rivers. J Aquat Animal Health 9:114-126

Evenden AJ, Grayson TH, Gilpin ML, Munn CB (1993) Renibacterium salmoninarum and bacterial kidney diseasethe unfinished jigsaw. Ann Rev Fish Dis 3:87-104

Gudmundsdottir S, Helgason S, Sigurjonsdottir H, Matthiasdottir S, Jonsdottir H, Laxdal B, Benediktsdottir E (2000) Measures applied to control Renibacterium salmoninarum infection in Atlantic salmon a retrospective study of two sea ranches in Iceland. Aquaculture 186:193-203

Hamel OS, Anderson JJ (2002) Relationship between antigen concentration and bacterial load in Pacific salmon with bacterial kidney disease. Dis Aquat Organ 51:85-92

Hendricks JD, Leek SL (1975) Kidney disease postorbital lesions in spring chinook salmon (Oncorhynchus tshawytscha). Trans Am Fish Soc 104:805-807

Jonsdottir H, Malmquist HJ, Snorrason SS, Gudbergsson G, Gudmundsdottir S (1998) Epidemiology of Renibacterium salmoninarum in wild Arctic charr and brown trout in Iceland. J Fish Biol 53:322-339

Kent ML, Traxler GS, Kieser D, Richard J, Dawe SC, Shaw RW, Prosperi-Porta G, Ketcheson J, Evelyn TPT (1998) Survey of salmonid pathogens in ocean-caught fishes in British Columbia, Canada. J Aquat Animal Health 10: 211-219

Krkosek M, Lewis MA, Volpe JP (2005) Transmission dynamics of parasitic sea lice from farm to wild salmon. Proc Royal Soc B 272:689-696

Levings CD, McAllister CD, Cheng BD (1986) Differential use of the Campbell River estuary, British Columbia, by wild and hatchery-reared juvenile chinook salmon. Can J Fish Aquat Sci 43:1386-1397

Maule AG, Rondorf DW, Beeman J, Haner P (1996) Incidence of Renibacterium salmoninarum infections in juvenile hatchery spring chinook salmon in the Columbia and Snake Rivers. J Aquat Animal Health 8:37-46

McIntosh D, Austin B, Flano E, Villena A, Martinez-Pereda JA, Tarazona JV (2000) Lack of uptake of Renibacterium salmoninarum by gill epithelia of rainbow trout. J Fish Biol 56:1053-1061

McKibben CL, Pascho RJ (1999) Shedding of Renibacterium salmoninarum by infected chinook salmon Oncorhynchus tschawytscha. Dis Aquat Org 38:75-79

Mesa MG, Maule AG, Poe TP, Schreck CB (1999) Influence of bacterial kidney disease on smoltification in salmonids: is it a case of double jeopardy? Aquaculture 174:25-41

Mesa MG, Maule AG, Schreck CB (2000) Interaction of infection with Renibacterium salmoninarum and physical stress in juvenile chinook salmon: Physiological responses, disease progression, and mortality. Trans Am Fish Soc 129: 158-173

Meyers TR, Short S, Farrington C, Lipson K, Geiger HJ, Gates R (1993) Comparison of the enzyme-linked immunosorbent assay (ELISA) and the fluorescent antibody test (FAT) for measuring the prevalences and levels of Renibacterium salmoninarum in wild and hatchery stocks of salmonid fishes in Alaska, USA. Dis Aquat Org 16: 181-189

Mitchum DL, Sherman LE (1981) Transmission of bacterial kidney disease from wild to stocked hatchery trout. Can J Fish Aquat Sci 38:547-551

Mitchum DL, Sherman LE, Baxter GT (1979) Bacterial kidney disease in feral populations of brook trout (Salvelinus 
fontinalis), brown trout (Salmo trutta), and rainbow trout (Salmo gairdneri). J Fish Res Bd Can 36:1370-1376

Moles A (1997) Effect of bacterial kidney disease on saltwater adaptation of coho salmon smolts. J Aquat Animal Health 9:230-233

Murray CB, Evelyn TPT, Beacham TD, Barner LW, Ketcheson JE, Prosperi-Porta L (1992) Experimental induction of bacterial kidney disease in chinook salmon by immersion and cohabitation challenges. Dis Aquat Org 12:91-96

Nagai T, Iida Y (2002) Occurrence of bacterial kidney disease in cultured ayu. Fish Path 37:77-81

Pascho RJ, Elliott DG, Streufert JM (1991) Brood stock segregation of spring chinook salmon Oncorhynchus tshawytscha by use of the enzyme-linked immunosorbent assay (ELISA) and the fluorescent antibody technique (FAT) affects the prevalence and levels of Renibacterium salmoninarum infection in progeny. Dis Aquat Org 12: 25-40

Pascho RJ, Elliott DG, Achord S (1993) Monitoring of the inriver migration of smolts from two groups of spring chinook salmon, Oncorhynchus tshawytscha (Walbaum),

Editorial responsibility: Julie Bebak-Williams, Shepherdstown, West Virginia, USA with different profiles of Renibacterium salmoninarum infection. Aquacult Fish Manage 24:163-169

Rhodes LD, Nilsson WB, Strom MS (1998) Sensitive detection of Renibacterium salmoninarum in whole fry, blood, and other tissues of Pacific salmon by reverse transcription-polymerase chain reaction. Mol Mar Biol Biotech 7:270-279

Sanders JE, Long JJ, Arakawa CK, Bartholomew JL, Rohovec JS (1992) Prevalence of Renibacterium salmoninarum among downstream-migrating salmonids in the Columbia River. J Aquat Animal Health 4:72-75

Seals Price C, Schreck CB (2003) Effects of bacterial kidney disease on saltwater preference of juvenile spring chinook salmon, Oncorhynchus tshawytscha. Aquaculture 222: 331-341

Starliper CE, Morrison P (2000) Bacterial pathogen contagion studies among freshwater bivalves and salmonid fishes. J Shellfish Res 19:251-258

Washington State Department of Fish and Wildlife (2005) Hatchery and genetic management plans (HGMPs) for WDFW Hatchery programs, available at http://wdfw.wa. gov/hat/hgmp/\#pugetsound

Submitted: December 28, 2005; Accepted: May 25, 2006 Proofs received from author(s): August 14, 2006 